\title{
Chemical Industry and Chemist's Jobs after the COVID-19 Pandemic: A Long-Term Prediction of Employment Outlook for Chemical Professionals
}

\author{
Sujata Guha1, Kaleh Karim ${ }^{1,2}$, Ryan Beni ${ }^{*}$ \\ ${ }^{1}$ Department of Chemistry, Tennessee State University, Nashville, TN, USA \\ ${ }^{2}$ Department of Biological Sciences, Tennessee State University, Nashville, TN, USA \\ Email: ^rbeni@tnstate.edu
}

How to cite this paper: Guha, S., Karim, K., \& Beni, R. (2020). Chemical Industry and Chemist's Jobs after the COVID-19 Pandemic: A Long-Term Prediction of Employment Outlook for Chemical Professionals. Voice of the Publisher, 6, 69-83. https://doi.org/10.4236/vp.2020.63007

Received: June 10, 2020

Accepted: September 1, 2020

Published: September 4, 2020

Copyright $\odot 2020$ by author(s) and Scientific Research Publishing Inc. This work is licensed under the Creative Commons Attribution International License (CC BY 4.0).

http://creativecommons.org/licenses/by/4.0/

(c) (i) Open Access

\begin{abstract}
In March 2020, the whole world was impacted by the ripple effects of COVID-19 and was in the midst of battling this infectious disease. A global pandemic caused by a microscopic enemy, which outbroke in Wuhan, China, quickly spread, bringing the world's largest economies to a halt. As a consequence, the financial infrastructures of several countries have been severely damaged. In just 3 weeks, unemployment claims surpassed 16 million in the United States alone, which soared to over 40 million by the end of May 2020. This accounts for a jobless rate of over $24 \%$, a record high in history. Production of chemicals that go into construction and consumer uses trended down in March, and continued plummeting downward in the following months. The chemical manufacturing sector showed a slight drop in employment rate. It is important to understand these broad trends in the demand for chemicals and unemployment in chemistry in the coming months and years. In an economic downturn, fewer people buy new houses and new cars, which decreases the demand for the chemicals that go into manufacturing them. The dramatic drops in the stock market will also affect the pharmaceutical sector. It may become harder for small biotech firms to raise money from investors and seed new positions in start-ups. For major chemical and pharmaceutical companies, if stock prices and quarterly results suffer, we may begin to see layoffs - a reversal of the hiring trends of the past few years. Academia will be affected as well. For many universities and colleges, the sudden disruption in the academic structure of the Spring 2020 semester is having an immediate financial impact. Hiring freezes have begun. However, the effects of the economic downturn on new tenure-track positions won't be clear until early Fall.
\end{abstract}


In this article we have investigated the worldwide effects of major wars and global recessions on the chemical industry. We have analyzed the effects on job market trends to achieve a comprehensive long-term prediction of employment outlook for chemical professionals. In this regard, we have compared the Great Depression, World War II, Cold War, and other recession periods to predict a 10-year pattern after each event. The current impacts of COVID-19 on manufacturing jobs, faculty positions, hiring freezes, and student graduation due to university closures have also been evaluated. Strategies for maximizing job opportunities during the current pandemic have been provided.

\section{Keywords}

Chemists Jobs, Chemical Industry, COVID-19 Pandemic, Coronavirus, Unemployment, Recession, Jobs

\section{Introduction (Great Depression Onward)}

The global conflict labeled World War II, which emerged from the Great Depression, destabilized governments, economies, and countries across the world. For the United States, the Great Depression and World War II were the most important economic events of the twentieth century. After World War II and the huge economic modification, the collection of many commercial indicators, such as unemployment and gross domestic product (GDP), became standardized. The major recessions, beginning with the Great Depression, are listed in Table 1.

The unemployment rate due to recession often reaches a peak after the recession has officially ended (U.S. Bureau of Labor Statistics, 2020b-Labor Force Statistics from the Current Population Survey). Until the start of the coronavirus pandemic in 2020, no post-World War II era came anywhere near the extent of the Great Depression. During the Great Depression, the Gross Domestic Product (GDP) fell by 27\%, the deepest after demobilization during the recession beginning in December 2007, during which GDP had fallen 5.1\% as of the second quarter of 2009. Additionally, the unemployment rate reached $10 \%$ during the Great Depression, which was the highest since the $10.8 \%$ rate reached during the 1981-82 recession (Labonte \& Makinen, 2003). The National Bureau of Economic Research dates recessions on a monthly basis back to 1854 . According to their chronology, from 1854 to 1919 , there were 16 cycles. The average recession lasted 22 months, and the average expansion 27 months. From 1919 to 1945, there were six cycles; recessions lasted an average of 18 months and expansions for 35 months. From 1945 to 2001, and 10 cycles, recessions lasted an average of 10 months and expansions an average of 57 months. This has prompted some economists to declare that the business cycle has become less severe (Knoop, 2004). Many factors may have contributed to this moderation, such as the establishment of deposit insurance in the form of the Federal Deposit Insurance 
Table 1. Recessions in the United States from the Great Depression onward.

\begin{tabular}{|c|c|c|c|c|c|}
\hline Recessionname & Time frame & Time Span & $\begin{array}{l}\text { Percent } \\
\text { unemployment }\end{array}$ & $\begin{array}{l}\text { Decrease } \\
\text { in GDP }\end{array}$ & Attributes \\
\hline $\begin{array}{l}\text { Great Depression (Eichengreen \& } \\
\text { Temin, 2000; Vedder \& Gallaway, } \\
\text { 1993; Coen, 1973) }\end{array}$ & $\begin{array}{l}\text { Aug 1929- } \\
\text { Mar } 1933\end{array}$ & $\begin{array}{l}3 \text { years and } \\
7 \text { months }\end{array}$ & $\begin{array}{l}21.3 \%(1932) \\
24.9 \%(1933)\end{array}$ & $-26.7 \%$ & $\begin{array}{l}\text { Significant duties on imports and exports } \\
\text { combined with other factors led to a collapse in } \\
\text { banking and monetary supply. This led to a loss } \\
\text { of GDP, industrial production, and employment. }\end{array}$ \\
\hline $\begin{array}{l}\text { Recession of 1937-1938 (Coen, 1973; } \\
\text { Smiley, 1997) }\end{array}$ & $\begin{array}{l}\text { May } 1937- \\
\text { June } 1938\end{array}$ & $\begin{array}{l}1 \text { year and } \\
1 \text { month }\end{array}$ & $\begin{array}{l}17.8 \%(1937) \\
19.0 \%(1938)\end{array}$ & $-18.2 \%$ & $\begin{array}{l}\text { This was among the worst recessions of the 20th } \\
\text { century, characterized by stiff financial and } \\
\text { budgetary policies adopted by the Federal } \\
\text { Reserve, and reduction in business profits. }\end{array}$ \\
\hline $\begin{array}{l}\text { Recession of 1945: following World } \\
\text { War II from 1939-1945 (Zarnovitz, } \\
\text { 1996; Rosnick, 2010) }\end{array}$ & $\begin{array}{l}\text { Feb } 1945- \\
\text { Oct } 1945\end{array}$ & 8 months & $\begin{array}{l}5.2 \% \\
(1946)\end{array}$ & $-12.7 \%$ & $\begin{array}{l}\text { There was a huge decline in GDP at the end of } \\
\text { World War II due to a transition in economy. }\end{array}$ \\
\hline $\begin{array}{l}\text { Recession of 1949: Cold War period, } \\
\text { beginning in } 1947 \text { (Zarnovitz, 1996; } \\
\text { Labonte \& Makinen, 2003) }\end{array}$ & $\begin{array}{l}\text { Nov } 1948- \\
\text { Oct } 1949\end{array}$ & 11 months & $\begin{array}{l}7.9 \% \\
(1949)\end{array}$ & $-1.7 \%$ & $\begin{array}{l}\text { This was a period of brief economic downturn, } \\
\text { followed by financial restrictions. }\end{array}$ \\
\hline $\begin{array}{l}\text { Recession of 1953: Cold War period } \\
\text { (Dell, 1957; Holmans, 1958) }\end{array}$ & $\begin{array}{l}\text { July } 1953- \\
\text { May } 1954\end{array}$ & 10 months & $\begin{array}{l}6.1 \% \\
(1954)\end{array}$ & $-2.6 \%$ & $\begin{array}{l}\text { After the inflationary period following the } \\
\text { Korean War, more funds were allocated to } \\
\text { national security. In 1952, the Federal Reserve } \\
\text { adopted a restrictive financial policy due to } \\
\text { concerns of further inflation. }\end{array}$ \\
\hline $\begin{array}{l}\text { Recession of 1958: Cold War period } \\
\text { (Labonte \& Makinen, 2003) }\end{array}$ & $\begin{array}{l}\text { Aug 1957- } \\
\text { April } 1958\end{array}$ & 8 months & $\begin{array}{l}7.5 \% \\
(1958)\end{array}$ & $-3.7 \%$ & $\begin{array}{l}\text { There was a } 0.6 \% \text { budget deficit of GDP in } 1958 \text {, } \\
\text { followed by } 2.6 \% \text { deficit of GDP in } 1959 \text {. }\end{array}$ \\
\hline $\begin{array}{l}\text { Recession of 1960-61: Cold War } \\
\text { period (Labonte \& Makinen, 2003) }\end{array}$ & $\begin{array}{l}\text { Apr 1960- } \\
\text { Feb } 1961\end{array}$ & 10 months & $\begin{array}{l}7.1 \% \\
(1961)\end{array}$ & $-1.6 \%$ & $\begin{array}{l}\text { Financial recession occurred after the Federal } \\
\text { Reserve raised interest rates in } 1959 .\end{array}$ \\
\hline $\begin{array}{l}\text { Recession of 1969-70: Cold War } \\
\text { period (Labonte \& Makinen, 2003) }\end{array}$ & $\begin{array}{l}\text { Dec } 1969- \\
\text { Nov } 1970\end{array}$ & 11 months & $\begin{array}{l}6.1 \% \\
(1970)\end{array}$ & $-0.6 \%$ & $\begin{array}{l}\text { Recession was relatively mild in } 1969 \text { followed a } \\
\text { protracted development. }\end{array}$ \\
\hline $\begin{array}{l}\text { Recession of 1973-75: Cold War } \\
\text { period (Merrill, 2007; Knoop, 2004) }\end{array}$ & $\begin{array}{l}\text { Nov } 1973- \\
\text { Mar } 1975\end{array}$ & $\begin{array}{l}1 \text { year and } \\
4 \text { months }\end{array}$ & $\begin{array}{l}9.0 \% \\
(1975)\end{array}$ & $-3.2 \%$ & $\begin{array}{l}\text { Oil crisis occurred in } 1973 \text {, leading to drastic } \\
\text { increase in oil prices, followed by the 1973-1974 } \\
\text { stock market crash. }\end{array}$ \\
\hline $\begin{array}{l}\text { Recession of 1980: Cold War period } \\
\text { (BBC News, 2009) }\end{array}$ & $\begin{array}{l}\text { Jan } 1980- \\
\text { July } 1980\end{array}$ & 6 months & $\begin{array}{l}7.8 \% \\
(1980)\end{array}$ & $-2.2 \%$ & $\begin{array}{l}\text { A very short recession occurred in } 1980 \text {, followed } \\
\text { by a short period of growth and then a deep } \\
\text { recession. }\end{array}$ \\
\hline $\begin{array}{l}\text { Recession of 1981-1982: Cold War } \\
\text { period (Rattner, 1981) }\end{array}$ & $\begin{array}{l}\text { July } 1981- \\
\text { Nov } 1982\end{array}$ & $\begin{array}{l}1 \text { year and } \\
4 \text { months }\end{array}$ & $\begin{array}{l}10.8 \% \\
(1982)\end{array}$ & $-2.7 \%$ & $\begin{array}{l}\text { In } 1979 \text { the Iranian Revolution dramatically } \\
\text { increased the price of oil across the world. This } \\
\text { lead to the } 1979 \text { energy crisis. }\end{array}$ \\
\hline $\begin{array}{l}\text { Recession of early 1990s: Cold War } \\
\text { and its end in } 1991 \text { (Walsh, 1993) }\end{array}$ & $\begin{array}{l}\text { July } 1990- \\
\text { Mar } 1991\end{array}$ & 8 months & $\begin{array}{l}7.8 \% \\
(1992)\end{array}$ & $-1.4 \%$ & $\begin{array}{l}\text { Inflation increased and the Federal Reserve } \\
\text { raised interest rates. }\end{array}$ \\
\hline $\begin{array}{l}\text { Recession of early 2000s (Kliesen, } \\
\text { 2003) }\end{array}$ & $\begin{array}{l}\text { Mar 2001- } \\
\text { Nov } 2001\end{array}$ & 8 months & $\begin{array}{l}6.3 \% \\
(2003)\end{array}$ & $-0.3 \%$ & $\begin{array}{l}\text { The dot-com bubble collapsed, leading to a } \\
\text { decline in businesses and investments. A series of } \\
\text { coordinated attacks against the U.S. took place } \\
\text { on September } 11 \text {. }\end{array}$ \\
\hline $\begin{array}{l}\text { Great Recession (Stark, 2010; } \\
\text { Economic Times Series Page, 2020; } \\
\text { U.S. Bureau of Economic Analysis, } \\
\text { 2020) }\end{array}$ & $\begin{array}{l}\text { Dec 2007- } \\
\text { June } 2009\end{array}$ & $\begin{array}{l}1 \text { year and } \\
6 \text { months }\end{array}$ & $\begin{array}{l}10.0 \% \\
(2009)\end{array}$ & $-5.1 \%$ & $\begin{array}{l}\text { Housing infrastructure collapsed in the United } \\
\text { States, leading to a global financial crisis. Prices } \\
\text { of oil and food rocketed. }\end{array}$ \\
\hline $\begin{array}{l}\text { COVID-19 Crisis (Cohen \& Hsu, } \\
\text { 2020; International Monetary Fund, } \\
\text { 2020) }\end{array}$ & $\begin{array}{l}\text { Mar 2020- } \\
\text { present }\end{array}$ & N/A & N/A & N/A & $\begin{array}{l}\text { Trade plunged downward leading to global } \\
\text { financial crisis and job losses. Stock market } \\
\text { responded negatively in technological sectors. }\end{array}$ \\
\hline
\end{tabular}


Corporation in 1933, and increased regulation of the banking sector (Barth et al., 2004; Kareken \& Wallace, 1978; Bhattacharya et al., 1998). Other changes include the use of fiscal policy as automatic stabilizers to alleviate cyclical volatility (McKay \& Reis, 2016). The creation of the Federal Reserve System in 1913 has been disputed as a source of stability, and its policies having mixed successes.

Since the early 1980s, the sources of the Great Moderation have been attributed to numerous causes including public policy, industry practices, technology, and even good luck (Goodfriend, 2011; Selgin et al., 2012; Ahmed, et al., 2004; The Federal Reserve Bond, 2004). The Great Depression was a banking panic, and a collapse in the money supply took place in the United States that was exacerbated by international commitment to the gold standard. Extensive new tariffs and other factors contributed to an extremely deep depression. GDP, industrial production, employment, and prices fell substantially. A small economic expansion within the depression began in 1933, with gold inflow expanding the money supply and improving expectations. That expansion ended in 1937. The ultimate recovery, which occurred with the beginning of World War II in September 1939, was credited to financial policy and expansion (Friedman, 1970; Irwin, 2010; Irwin, 2011; Romer, 1992).

\section{Chemical Industry Outlook}

Following the end of the twentieth century, due to trade problems and passive growth in several key end-use chemicals markets, the production of chemicals in the United States increased at a slower rate, as in 2019, according to the American Chemistry Council (American Chemistry Council, 2020). Weak global manufacturing and uncertain trade policy is predicted due to trade problems and passive growth in several key end-use chemicals markets, to continuously moderate growth in the U.S. chemical production in 2020. In contrast, the establishment of new capacity linked to the advantage of shale gas will provide headwinds. In 2019, total trade in chemicals in the United States was projected to contract 3\% to $\$ 242$ billion, then recover 1\% in 2020. This forecast was made in early 2019 with conservation optimism for growth in 2020. Manufacturing chemicals in the United States has a competitive advantage in the world markets, due to the abundant and affordable supply of energy and raw materials.

Since 2010, the chemical industry has announced 340 projects with a cumulative value of $\$ 204$ billion. The total volume of chemical production (excluding pharmaceuticals) increased by $0.6 \%$ in 2019 and was projected to increase by $0.4 \%$ in 2020, before strengthening to reach 2.3\% in 2021 (American Chemistry Council, 2020). However, the current pandemic has changed these forecasts. The sudden drop in crude oil prices completely dampened the shale-favored U.S. investment.

The oil industry has created well-paying American jobs for the seventh consecutive year. Pursuing a tradition of innovation, companies remain committed to providing essential materials to a growing population and finding sustainable 
solutions for the future. The chemicals sector is a $\$ 553$ billion business and one of America's largest manufacturing industries, accounting for more than $10 \%$ of all U.S. exports and $14 \%$ of the world's chemicals. More than $96 \%$ of all manufactured products are affected by chemicals (Jenkins, 2019). At the end of February 2020, the German chemical group BASF was worried about its prospects for 2020, due to the impacts of the coronavirus pandemic. In a statement released on February 28, 2020 alongside its 2019 fiscal year, the BASF stated that the viral infection could lead to a second year of reduced profits for the company and decrease global chemical production to around 1.2\% (Industry Week, 2020). It would be the industry's worst growth since the Great Recession of 2008 and a significant drop from 2019, where it had increased $1.8 \%$. The automotive market represents around $20 \%$ of BASF's sales.

Figure 1 shows the chemical activity barometer vs. industrial production for a short-term period of 2001-2020 as well as long-term period of 1948-2020. American Chemical Council's Chemical Activity Barometer (American Chemistry Council,

\section{Chemical Activity Barometer (CAB): 1948-2020}

Index where $2012=100$ (3MMA)

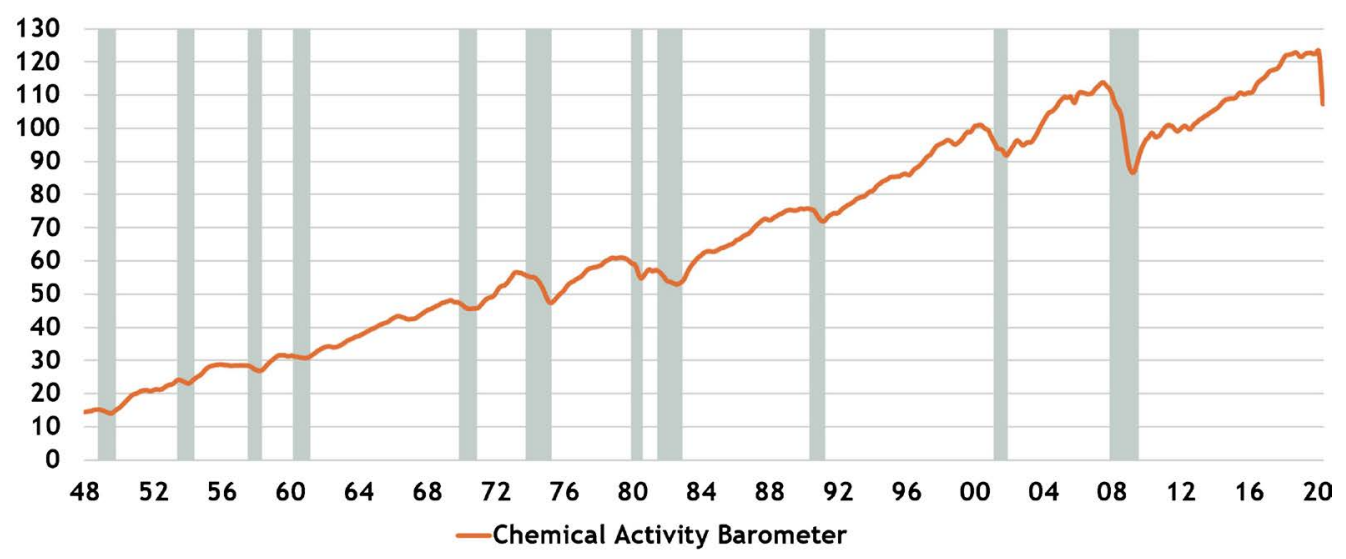

\section{Chemical Activity Barometer vs. Industrial Production Index}

\section{$\%$ Change Year-over-Year (3MMA)}

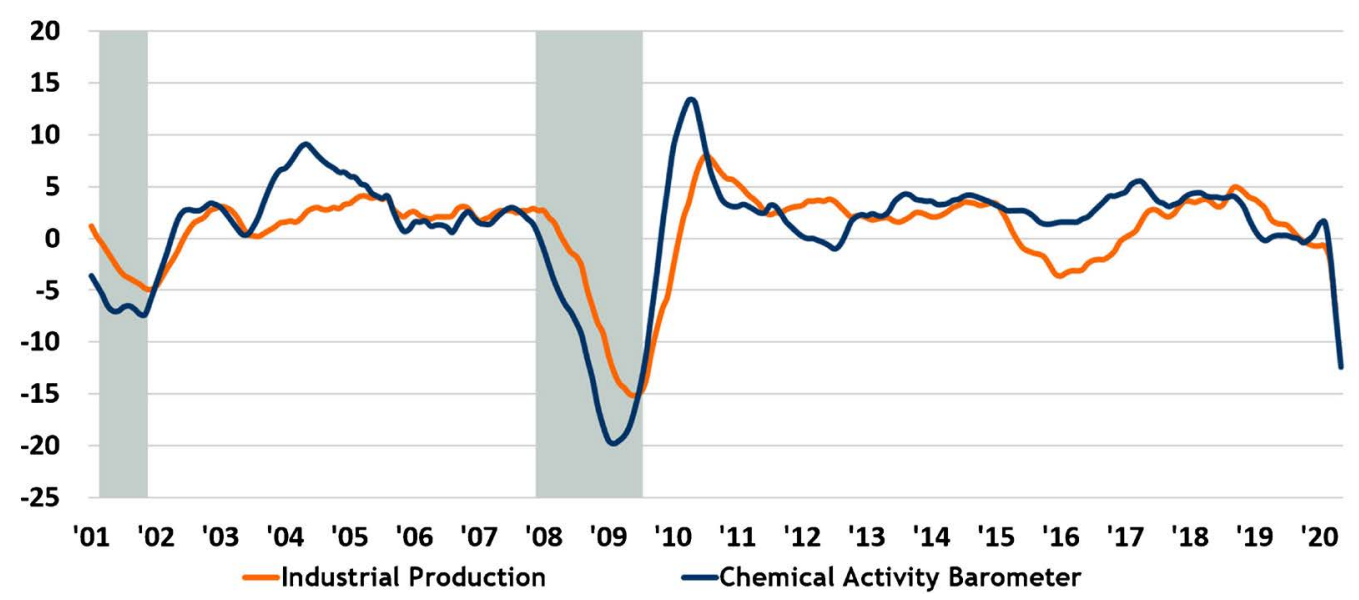

Figure 1. Chemical Activity Barometer vs. Industrial Production (American Chemistry Council, 2020). 
2020) is the first-of-its-kind leading economic indicator that helps anticipate peaks and troughs in the overall U.S. economy, and highlights potential trends in other industries in the country. This barometer can be a critical tool for predicting broader economic health in the United States.

\section{Chemical Education and the Academic Job Outlook}

Many scientists have been affected by university closures, particularly those who had to totally shut down or postpone their research work, due to COVID-19. This situation is a major threat to the scientist's career. Several universities have canceled or postponed job searches. The disruptions will impact the careers of researchers at all seniority levels, but the greatest impact will be on early-career scientists (Yan, 2020). Undergraduate students will not be able to build their skills through summer internships this year, since many of them are getting canceled. When professors begin to review graduate school applications later, those who have little research experience will be considered as less competitive.

For students who are already in graduate school, the university closures might delay graduation. Students doing field or lab research had to stop work when the universities closed down in April due to the coronavirus. The situation has been particularly tough for Ph.D. students who anticipated defending their dissertations during summer this year. All doctoral programs in the United States require candidates to have one first-author paper in press at the time of graduation. Due to sudden closure in lab work, many students may not be able to submit a manuscript for publication, which may delay their graduation. The closures have impacted publication records, at least in the short term. The situation may be slightly better for students who do modeling, and have the opportunity to complete their Ph.D. from home (Yan, 2020).

Due to the far-reaching impacts of COVID-19, colleges and universities in the United States and Canada are analyzing their financial situations. The University of Arizona has estimated a $\$ 250$ million loss due to the pandemic, and many colleges and universities have announced a hiring freeze (Chemjobber, 2020b). Yale University has decided to not hire tenure-track faculty for the next academic year, until June 30, 2021 (Chemjobber, 2020b). Other U.S. institutions who have announced hiring/salary freezes include Brown University, University of Nevada-Las Vegas, Duke University, Virginia Polytechnic Institute and State University, Western Michigan University, Indiana University, University of Pennsylvania, University of Oklahoma, University of Utah, Florida State University, New York University, University of Montana, University of Kentucky, University of Louisville, Northern Michigan University, Miami University, Ohio State University, Pennsylvania State University, Syracuse University, Kansas State University, University of Colorado-Denver, Washington State University, University of Alabama, Purdue University, University of Wisconsin-Madison, Villanova University, Harvard University, and Vanderbilt University (Brown University, 2020; University of Nevada, Las Vegas, 2020; Forinash, 2020; Gen- 
dreau, 2020; Davis, 2020; Indiana University, 2020; Meisenzahl, 2020; The University of Oklahoma, 2020; The University of Utah, 2020; Florida State University, 2020; New York University, 2020; Neuman, 2020; News Break, 2020; Weiter, 2020; Northern Michigan University, 2020; Bright, 2020; The Ohio State University, 2020; WILK Newsroom, 2020; Weiner, 2020; Darr, 2020; University of Colorado, 2020; Washington State University, 2020; Jackson, 2020; Bangert, 2020; University of Wisconsin-Madison, 2020; Villanova University, 2020; Kim, 2020; Durchholz \& Milton, 2020). Tenure-track positions at colleges and universities in the United States and Canada begin to appear in early summer and reach a steady pace in August and September, with most positions having application deadlines between September 1 and October 31. Due to the economic crisis related to COVID-19, fewer positions will be announced during the 2020-2021 academic year. Currently it is uncertain if Ph.D.-granting institutions will post more positions over small colleges, or, for the positions posted, which sub-fields of chemistry will be the most popular. This puts graduate students and postdoctoral fellows, who planned to apply for faculty positions during the Summer and Fall of 2020, in an undesirable situation. If only a few academic positions are posted in August and September of 2020, applicants will have to wait an extra year for more positions to be posted, without any guarantee that the situation will improve in a year (Chemjobber, 2020b).

Many scientists are worried that they'll have a harder time securing federal research grants and other forms of funding as the economy heads into a recession (Yan, 2020). Students working as postdocs may hope to land a faculty job that hasn't been canceled. If those don't bear fruit, they will likely apply for industry jobs. Postdocs who move into her tenure-track position hope that their universities will fairly evaluate any delays in new faculty members' research and progress.

Figure 2 shows that the unemployment continued to mount for new graduates and drop for experienced chemists and chemical engineers, during the Great Recession. Talented and motivated chemists and chemical engineers who can adjust to the uncertainty of the COVID-19 pandemic and quickly find affordable solutions,

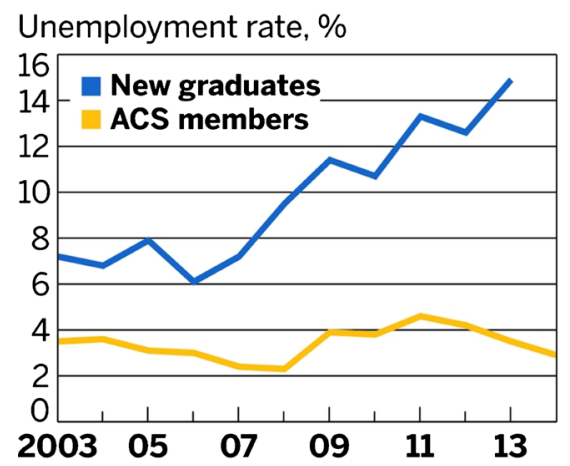

Figure 2. Opposing trends: Unemployment rates of new graduate chemists versus all other American Chemical Society (ACS) members during the Great Recession of 2007-2009 (Rovner, 2014). 
will be in high demand across the pharmaceutical and chemical industries. While employment may remain subdued in the short-term, trends show that, in the medium- to long-term, there will be no shortage of work for chemists and engineers.

\section{Future of the Chemical Job Market}

Jobs in chemistry provide scientists the opportunity to solve fascinating problems, and an opportunity to create something interesting and useful. Most of these positions pay well and provide good benefits (Rovner, 2014; Chemjobber, 2019a). During an economic turbulence and decline, layoffs become a matter of concern, similar to the last great recession from December 2007 to June 2009. During that time, and for years afterward, there seemed to be an announcement every other month about a group of scientists that would be needing to find new jobs. Due to the current coronavirus pandemic, layoffs may be on the rise again. The reductions were already instituted in the pharmaceutical industry, and had risen by $16 \%$ in the chemical industry in 2018 . It is very difficult for chemists to maintain sanity during uncertain economic times, as there is a chance of possible disruption in their careers.

During the Great Recession which started from December 2007, Pfizer was the pioneer of layoffs in pharmaceutical industries. In October 2019 Merck, the international pharmaceutical giant, announced mass layoffs that will hit its sales personnel based in suburban Philadelphia. About 500 people affiliated with Merck's offices in Lansdale and Upper Gwynedd would lose their jobs in permanent workforce reductions, the company stated in a letter it filed with the Pennsylvania Department of Labor and Industry. During the same month, Johnson \& Johnson had stated its plans to eliminate 297 employees at its Wayne facility (Wood, 2019).

According to the U.S. Bureau of Labor Statistics, the overall employment of chemists and materials scientists was projected to grow 4\% from 2018 to 2028, similar to other occupations. In the pharmaceutical, medical, and chemical manufacturing industries, chemists are needed to develop nanotechnology for medicinal uses, and improve environmental safety in the workplace and community. Chemists with laboratory experience through cooperative programs or internships, are likely to meet with better prospects of employment after graduation (U.S. Bureau of Labor Statistics, 2020a-Chemicals and Material Scientists: Job Outlook; Wang \& Widener, 2020; Chemjobber, 2020a; Scott, 2020; Chemjobber, 2019b). Table 2 shows the employment projections data for chemists and materials scientists, for 2018-28. Since this projection was made in 2018, the recession due to the current pandemic was not accounted for.

The global chemical and materials industry is undergoing a full-fledged transformation due to the COVID-19 pandemic, leading to a high demand for defensive gears and disinfectants, increased call for antimicrobial supplements, and a rise in the absorption of plastic and glass for constructing protective 
Table 2. Employment projections data for chemists and materials scientists, 2018-28 (U.S. Bureau of Labor Statistics, 2020a-Chemicals and Material Scientists: Job Outlook).

\begin{tabular}{ccccc}
\hline \multirow{2}{*}{ Occupational Title } & $\begin{array}{c}\text { Employment, } \\
\text { 2018 }\end{array}$ & $\begin{array}{c}\text { Projected } \\
\text { Employment, 2028 }\end{array}$ & \multicolumn{2}{c}{ Change, 2018-28 } \\
\cline { 4 - 6 } & Percent & Numeric \\
\hline Chemists and materials scientists & 95,800 & 99,300 & 4 & 3500 \\
Materials scientists & 8100 & 8300 & 3 & 200 \\
Chemists & 87,700 & 90,900 & 4 & 3300 \\
\hline
\end{tabular}

equipment. However, it is predicted that the industry may suffer in the coming days due to economic restraints and disruptions of supply groups (Market Watch, 2020). On the other hand, the chemical market could get better opportunities, with increased demand for textile fabrics to be used for various health and hygiene products. The chemicals segment can progress rapidly as the demand for sanitizers and various medicines are increasing.

Countries like Germany and Switzerland are extending their healthcare support to the world, which entails a constant influx of necessary chemicals to counter the effect of COVID-19. Several companies, including some in the United States, have increased their production of chemicals to support the fight against the pandemic. However, the production is getting channelized, which can impact the outcome of other segments (basic chemicals, specialty chemicals, advanced materials, polymers and plastics, renewable chemicals, as well as metals and alloys) in the near future. Several firms are incorporating measures, different from their standard processes, which will also influence the market's outcome of in the days to come. Arkema (France) increased its production of alcohol-based solutions for the healthcare industry. Lanxess (Germany) increased their production of high-level disinfectants. Tata Chemicals (India) decided to shut down their productions in three plants. Milliken and Company decided to expand their manufacture of antimicrobial fabrics, and Air Liquide S.A. (U.S.) increased their production of medical gases (Market Watch, 2020).

\section{Job-Seeking Strategies for Chemical Professionals}

Due to the uncertainty in job prospects caused by the COVID-19 pandemic, students in their senior/final year at universities, recent graduates, and other job seekers need a proper plan, in order to boost their chances of employment. Some important tips provided by recruiters are as follows (Top Universities, 2020; Friedman, 2020; Roepe, 2020):

1) Perform in-depth research and uncover the companies or institutions which are hiring.

2) Complete a personal SWOT (Strengths, Weaknesses, Opportunities, Threats) analysis, to have a clear idea of the skills needed for improvement. Focus on building resume accordingly.

3) Create a one-page document that lists the target industry, companies, job titles, etc. Keep an eye on the company websites. Apply early and flexible about 
job interests.

4) Practice mock interviewing virtually with a friend or professional contact. Make sure to have the correct camera angle with no background distractions.

5) Focus on professional networking and relationship-building, connect with alumni who are working at various places, and reach out to recruiters. Ask the school's career center for networking opportunities and guidance. Obtain a referral from a professional, which can increase the chances of getting the desired job.

6) Join professional groups on LinkedIn and Facebook, and follow the companies of interest on social media. Connect with like-minded professionals online and ask about virtual events.

7) Set Google alerts for companies of interest, and listen to investor/earnings calls, to obtain an understanding of the leadership's concerns and threats faced by the company due to the pandemic. This will provide a better insight of how to help the company achieve its goals, upon interview and hire.

\section{Conclusion}

The coronavirus pandemic transitioned from a health crisis to a financial one, shattering businesses, capsizing entire industries, and sending financial markets staggering. These are the short-term and mostly reversible impacts on societies. The long-lasting impacts on international trade, wealth disparities, manufacturing hubs, and supply chains need to be redefined. For especially students in their senior year seeking jobs, or newly graduated chemists, positive mental attitude is very important. This will enable them to stay on track and try different options, so that they can make the most of their potential. It is critical to not have a pessimistic attitude, as there are vast opportunities awaiting chemists. During an economic slowdown, such as the one caused by the COVID-19 pandemic, it is of essence to focus on what people can control. Prospective job applicants should improve their skills and participate in networking opportunities. It is important to lay the groundwork now, so that when the crisis is over, the applicants have open opportunities. Throughout this period of crisis, it is very important to have a focused career plan, stay alert, and remain motivated.

\section{Conflicts of Interest}

The authors declare no conflicts of interest regarding the publication of this paper.

\section{References}

Ahmed, S., Levin, A., \& Wilson, B. A. (2004). Recent US Macroeconomic Stability: Good Policies, Good Practices, or Good Luck? Review of Economics and Statistics, 86, 824-832. https://doi.org/10.1162/0034653041811662

American Chemistry Council (2020). Chemical Activity Barometer vs Industrial Production. https://www.americanchemistry.com/CAB-vs-Industrial-Production 
Bangert, D. (2020). Coronavirus: Purdue Tells Most Staff to Keep Working from Home through June. Lafayette Journal \& Courier.

https://www.jconline.com/story/news/2020/04/28/coronavirus-purdue-tells-most-staffkeep-working-home-through-june/3038725001

Barth, J. R., Caprio Jr., G., \& Levine, R. (2004). Bank Regulation and Supervision: What Works Best? Journal of Financial Intermediation, 13, 205-248.

https://doi.org/10.1016/j.jfi.2003.06.002

BBC News (2009). The Recession Is a Pretty Picture. http://news.bbc.co.uk/2/hi/business/8224199.stm

Bhattacharya, S., Boot, A. W., \& Thakor, A. V. (1998). The Economics of Bank Regulation. Journal of Money, Credit and Banking, 30, 745-770.

https://doi.org/10.2307/2601127

Bright, G. (2020). Miami University Freezes Hiring as Pandemic Affects Finances. The Miami Student.

https://www.miamistudent.net/article/2020/03/miami-university-freezes-hiring-as-pan demic-affects-finances?ct=content_open \&cv=cbox_featured

Brown University (2020). Changes to Hiring and Performance Evaluations. https://covid.brown.edu/news/2020-03-23/hiring

Chemjobber (2019a). Layoffs on the Mind. Chemical \& Engineering News, 97, 29. https://cen.acs.org/careers/employment/Layoffs-on-the-mind/97/i45 https://doi.org/10.1021/cen-09745-feature4

Chemjobber (2019b). What Is This Layoff Season Going to Look Like? http://chemjobber.blogspot.com/2019/11/what-is-this-layoff-season-going-to.html

Chemjobber (2020a). Get Ready for a Potential Chemistry Job Crisis. Chemical \& Engineering News, 98, 25. https://doi.org/10.1021/cen-09815-feature4 https://cen.acs.org/careers/career-tips/ready-potential-chemistry-job-crisis/98/i15

Chemjobber (2020b). Want a Faculty Position? Get Ready to Wait. Chemical \& Engineering News.

https://cen.acs.org/careers/employment/Want-faculty-position-ready-wait/98/i18

Coen, R. M. (1973). Labor Force and Unemployment in the 1920s and 1930s: A Re-Examination Based on Postwar Experience. The Review of Economics and Statistics, 55, 46-55. https://doi.org/10.2307/1927993

Cohen, P., \& Hsu, T. (2020). Sudden Black Hole for the Economy with Millions More Unemployed. New York Times.

https://www.nytimes.com/2020/04/09/business/economy/unemployment-claim-numbe rs-coronavirus.html

Darr, D. (2020). Kansas State University Announces Hiring Freeze Effective Immediately. KMAN News Radio. https://1350kman.com/kansas-state-university-announces-hiring-freeze

Davis, P. (2020). WMU Board of Trustees Approves Updated Contract with Faculty Union. Western Michigan University News. https://wmich.edu/news/2020/05/59586

Dell, S. (1957). The United States Recession of 1953/54: A Comment. The Economic Journal, 67, 338-339. https://doi.org/10.2307/2227810

Durchholz, E., \& Milton, I. J. (2020). Federal Coronavirus Grant Gives an Additional $\$ 1,100$ to Students Most in Need. Vanderbilt Hustler.

Economic Times Series Page (2020). The Unemployment Rate: Percent: SA. http://www.economagic.com/em-cgi/data.exe/fedstl/unrate

Eichengreen, B., \& Temin, P. (2000). The Gold Standard and the Great Depression. Con- 
temporary European History, 9, 183-207. https://doi.org/10.1017/S0960777300002010

Florida State University (2020). Hiring Freeze: Frequently Asked Questions. https://hr.fsu.edu/PDF/publications/employment/Hiring_Freeze_FAQ_2020-3-20.pdf

Forinash, C. (2020). Duke Freezes Hiring, Halts New Construction as Part of Financial Response to COVID-19. The Chronicle, Duke University. https://www.dukechronicle.com/article/2020/04/duke-university-halts-construction-pa y-raise-finances-coronavirus-covid-19

Friedman, J. (2020). How College Students Can Get a Job Amid COVID-19. US News \& World Report.

https://www.usnews.com/education/best-colleges/articles/how-college-students-can-ge t-a-job-internship-during-coronavirus

Friedman, M. (1970). The Counter-Revolution in Monetary Theory: First Wincott Memorial Lecture, Delivered at the Senate House, University of London, 16 September 1970 (Vol. 33). London: Institute of Economic Affairs.

Gendreau, H. (2020). Virginia Tech Freezes Most Hiring, Moves Summer Classes Online. The Roanoke Times.

https://www.roanoke.com/news/education/virginia-tech-freezes-most-hiring-moves-su mmer-classes-online/article_0097c464-684a-5b4a-ade2-550f02471d7f.html

Goodfriend, M. (2011). Central Banking in the Credit Turmoil: An Assessment of Federal Reserve Practice. Journal of Monetary Economics, 58, 1-12.

https://doi.org/10.1016/j.jmoneco.2010.09.008

Holmans, A. E. (1958). The Eisenhower Administration and the Recession, 1953-55. OXford Economic Papers, 10, 34-54. https://doi.org/10.1093/oxfordjournals.oep.a040794

Indiana University (2020). IU Employees and Coronavirus COVID-19. https://hr.iu.edu/relations/coronavirus.html\#loaded

Industry Week (2020). COVID-19 Is Coming for the Chemical Industry in 2020, BASF Predicts.

https://www.industryweek.com/supply-chain/planning-forecasting/article/21125045/co vid19-is-coming-for-the-chemical-industry-in-2020-basf-frets

International Monetary Fund (2020). Opening Remarks at a Press Briefing by Kristalina Georgieva Following a Conference Call of the International Monetary and Financial Committee.

https://www.imf.org/en/News/Articles/2020/03/27/sp032720-opening-remarks-at-pres s-briefing-following-imfc-conference-call

Irwin, D. A. (2010). Did France Cause the Great Depression? No. w16350. National Bureau of Economic Research. https://doi.org/10.3386/w16350

Irwin, D. A. (2011). Peddling Protectionism: Smoot-Hawley and the Great Depression. Princeton, NJ: Princeton University Press. https://doi.org/10.23943/princeton/9780691150321.001.0001

Jackson, L. (2020). University of Alabama System Suffers Millions in Losses, Considering Pay Cuts and Furloughs. Advance Local. https://www.al.com/education/2020/04/university-of-alabama-system-suffers-millionsin-losses-considering-pay-cuts-and-furloughs.html

Jenkins, S. (2019). ACC Chemical Industry Outlook Predicts Slower Growth Rate and Headwinds. Chemical Engineering.

https://www.chemengonline.com/acc-chemical-industry-outlook-predicts-slower-grow th-amid-headwinds

Kareken, J. H., \& Wallace, N. (1978). Deposit Insurance and Bank Regulation: A Par- 
tial-Equilibrium Exposition. Journal of Business, 51, 413-438.

https://doi.org/10.1086/296006

Kim, J. (2020). Harvard to Impose a Salary and Hiring Freeze Due to Fallout from Coronavirus Outbreak. $C N B C$.

https://www.cnbc.com/2020/04/14/harvard-announces-salary-and-hiring-freeze-due-t o-coronavirus.html

Kliesen, K. L. (2003). The 2001 Recession: How Was It Different and What Developments May Have Caused It? (pp. 23-28). St. Louis: The Federal Reserve Bank of St. Louis. https://web.archive.org/web/20091122134332/http:/research.stlouisfed.org/publications /review/03/09/Kliesen.pdf https://doi.org/10.3886/ICPSR01292

Knoop, T. A. (2004). Recessions and Depressions: Understanding Business Cycles. Westport, CT: Praeger Publishers.

Labonte, M., \& Makinen, G. (2003). The Current Economic Recession: How Long, How Deep, and How Different from the Past? Congressional Research Service: The Library of Congress.

http://congressionalresearch.com/RL31237/document.php?study=The+Current+Econ omic+Recession+How+Long+How+Deep+and+How+Different+from+the+Past

Market Watch (2020). COVID-19 Outbreak Impact on Chemicals \& Materials Market Current Status and Future Analysis.

https://www.marketresearchfuture.com/press-release/covid-19-impact-chemicals-mate rials-market

McKay, A., \& Reis, R. (2016). The Role of Automatic Stabilizers in the US Business Cycle. Econometrica, 84, 141-194. https://doi.org/10.3982/ECTA11574

Meisenzahl, E. (2020). University Hiring Freeze Will Not Affect Lecturers, Penn Med Employees, or TAs. The Daily Pennsylvanian.

https://www.thedp.com/article/2020/04/penn-hiring-freeze-med-teaching-assistants-le cturers

Merrill, K. R. (2007). The Oil Crisis of 1973-1974: A Brief History with Documents. Bedford/St. Martin's.

Neuman, M. (2020). COVID-19 Spurs Montana University System Hiring Freeze. Missoulian.

https://missoulian.com/news/local/covid-19-spurs-montana-university-system-hiring-f reeze/article_4ecffe09-013c-5db5-b0dd-c8a7af9c300a.html

New York University (2020). Taking Stock-The Impact of COVID-19 and Looking to the Future.

https://www.nyu.edu/about/leadership-university-administration/office-of-the-preside $\underline{\mathrm{nt} / \text { communications/taking-stock-the-impact-of-covid-19-and-looking-to-the-future.ht }}$ $\underline{\mathrm{ml}}$

News Break (2020). University of Kentucky under Hiring Freeze. https://www.newsbreak.com/kentucky/lexington/news/0OXw07iT/university-of-kentu cky-under-hiring-freeze

Northern Michigan University (2020). Q\&A for Faculty and Staff. https://www.nmu.edu/hr/covid

Rattner, S. (1981). Federal Reserve Sees Little Growth in 81 with Continued High Rates. New York Times.

https://archive.is/20120716061649/http:/select.nytimes.com/gst/abstract.html?res=FA0 F13FE3C5F0C768CDDA80894D9484D81\&scp=1\&sq=Federal+Reserve+Sees+Little+G rowth+in+'81+With+Continued+High+Rates\&st=nyt 
Roepe, L. R. (2020). What Does the Coronavirus Pandemic Mean for Your Job Search? The Muse: Finding A Job. https://www.themuse.com/advice/job-search-coronavirus

Romer, C. D. (1992). What Ended the Great Depression? The Journal of Economic History, 52, 757-784. https://doi.org/10.1017/S002205070001189X

Rosnick, D. (2010). Clearing Up Some Facts about the Depression of 1946. Washington DC: Center for Economic and Policy Research.

https://www.cepr.net/clearing-up-some-facts-about-the-depression-of-1946

Rovner, S. L. (2014). Demand for Chemists Up, Somewhat. Chemical \& Engineering News. https://cen.acs.org/articles/92/i44/Demand-ChemistsSomewhat.html

Scott, J. (2020). Chemical Industry Outlook: Uncertainty and Downside Risks Linked to COVID-19. American Chemistry Council.

https://www.americanchemistry.com/Media/PressReleasesTranscripts/ACC-news-relea ses/Chemical-Industry-Outlook-Uncertainty-and-Downside-Risks-Linked-to-COVID19.html

Selgin, G., Lastrapes, W. D., \& White, L. H. (2012). Has the Fed Been a Failure? Journal of Macroeconomics, 34, 569-596. https://doi.org/10.1016/j.jmacro.2012.02.003

Smiley, W. G. (1997). Depression of 1937-1938. In D. Glasner, \& T. F. Cooley (Eds.), Business Cycles and Depressions: An Encyclopedia (pp. 154-155). New York: Garland Publishing.

Stark, B. (2010). Tracking the Dow One Year after Rock Bottom. ABC News. https://abcnews.go.com/Business/year-ago-today-dow-hit-bottom-recession/story?id= 10046578

The Federal Reserve Bond (2004). Remarks by Governor Ben S. Bernanke. In the Meetings of the Eastern Economic Association. The Great Moderation. https://www.federalreserve.gov/boarddocs/speeches/2004/20040220

The Ohio State University (2020). COVID-19. https://hr.osu.edu/coronavirus

The University of Oklahoma (2020). Recruitment \& Hiring. https://hr.ou.edu/Managers-HR-Payroll-Coordinators/Hiring-Employment/Recruitme nt-Hiring

The University of Utah (2020). University of Utah Temporary Hiring Freeze. https://www.hr.utah.edu/serviceTeams/HiringFreeze.php

Top Universities (2020). How Graduates Can Get Hired during Coronavirus Pandemic https://www.topuniversities.com/student-info/careers-advice/how-graduates-can-get-h ired-during-coronavirus-pandemic

U.S. Bureau of Economic Analysis (2020). Frequently Asked Questions. https://www.bea.gov/help/faq?faq_id=1004

U.S. Bureau of Labor Statistics (2020a). Chemicals and Material Scientists: Job Outlook. https://www.bls.gov/ooh/life-physical-and-social-science/chemists-and-materials-scien tists.htm\#: :text=in\%20May\%202019.-,Job\%20Outlook,expected\%20to\%20have\%20be tter\%20opportunities.

U.S. Bureau of Labor Statistics (2020b). Labor Force Statistics from the Current Population Survey. https://www.bls.gov/cps

University of Colorado (2020). HR Recruitment. https://www.cu.edu/employee-services/collaborative-hr-services/hr-recruitment

University of Nevada, Las Vegas (2020). COVID-19 Response. https://www.unlv.edu/coronavirus/staff

University of Wisconsin-Madison (2020). Provost Statement on Hiring Freeze. 
https://news.wisc.edu/provost-statement-on-hiring-freeze

Vedder, R. K., \& Gallaway, L. E. (1993). Out of Work: Unemployment and Government in Twentieth-Century America (p. 77). New York: Holmes and Meier.

Villanova University (2020). COVID-19 University Updates. https://www1.villanova.edu/university/coronavirus/updates.html

Walsh, C. E. (1993). What Caused the 1990-1991 Recession? Economic Review of the Federal Reserve Bank of San Francisco, No. 2, 34-48.

Wang, L., \& Widener, A. (2020). Coronavirus Dims Chemistry Job Market Prospects. Chemical \& Engineering News.

https://cen.acs.org/careers/employment/Coronavirus-dims-chemistry-job-market/98/i $\underline{18}$

Washington State University (2020). COVID-19 Hiring Freeze. https://hrs.wsu.edu/covid-19-hiring-freeze

Weiner, M. (2020). Syracuse University Plans Pay Cuts, Hiring Freeze after \$35M Loss from Coronavirus Pandemic.

https://www.syracuse.com/coronavirus/2020/04/syracuse-university-plans-pay-cuts-hir ing-freeze-after-35m-loss-from-coronavirus-pandemic.html

Weiter, T. (2020). University of Louisville Cuts Pay, Furloughs Employees Due to COVID-19. WHAS11.

https://www.whas11.com/article/news/local/louisville-furloughs-employees-pay-cuts/4 17-e784c496-f229-4376-9b56-073983046c4c

WILK Newsroom (2020). Penn State University: No Job Cuts, for Now. https://wilknews.radio.com/articles/news/psu-to-continue-paying-staff-for-now

Wood, S. (2019). Pharma Giant Merck to Slash 500 Jobs Based in Philly Suburbs; J\&J to Lay Off 300. The Philadelphia Inquirer.

https://www.inquirer.com/business/merck-layoffs-lansdale-north-wales-reduction-in-f orce-pharmaceuticals-20191017.html

Yan, W. (2020). Early Career Scientists at Critical Career Junctures Brace for Impact of COVID-19. Science Magazine. https://doi.org/10.1126/science.caredit.abc1291 https://www.sciencemag.org/careers/2020/04/early-career-scientists-critical-career-jun ctures-brace-impact-covid-19

Zarnovitz, V. (1996). Business Cycles: Theory, History, Indicators, and Forecasting. Chicago, IL: University of Chicago Press.

https://vanderbilthustler.com/31461/featured/federal-coronavirus-grant-gives-an-addit ional-1100-to-students-most-in-need 